Umer Iftikhar*, Muhammad Jam e Kausar Ali Asghar**, Hamad Khan**, Hammad Hassan Mirza***

\title{
THE CORPORATE GOVERNANCE AND EFFICIENCY OF COMMERCIAL BANKS IN PAKISTAN: APPLICATION OF THE NON-PARAMETRIC APPROACH
}

This study examined the relationship of Corporate Governance (CG) on the efficiency of commercial banks listed on the Pakistan Stock Exchange (PSX) over the period from 2005 to 2014. The CG of commercial banks is measured with the composite CG index which is further subdivided into: board of directors, audit committee, disclosure and transparency, remuneration committee and shareholder's rights. The Data Envelopment Analysis (DEA) approach is used to measure the technical efficiency (TE) and cost efficiency (CE) whereas the Tobit regression model is used to investigate the relationship between $\mathrm{CG}$ and both efficiency scores. The results for the composite CG index suggest that there is a positive and significant relationship of CG with both TE and CE of commercial banks. Moreover, the subindices also validate our results as they were mostly found positively and significantly associated with both efficiencies.

Keywords: CG index, technical efficiency, cost efficiency, DEA, commercial banks DOI: $10.15611 /$ aoe.2019.2.07

\section{INTRODUCTION}

It has turned into a worldwide dictum that the quality of corporate governance $(\mathrm{CG})$ has a critical effect on the efficiency of commercial banks. The level of CG compliance describes that how much a firm is run in a transparent way (Sanusi, 2003). Hence, the practice of effective CG involves compliance with the statutory regulations, transparency, accurate reporting, and openness etc. Historically, predecessors demonstrate that recession or financial crisis is an immediate outcome of the absence of good CG in banks; invariably one of the sources of instability in the banking sector is a lack or inadequate practice of CG (Kirkpatrick, 2009).

CG practices are important for any industry, particularly for the banking industry since it has the major contribution in the overall economic growth

\footnotetext{
* Department of Commerce, University of Sargodha, Bhakkar, Pakistan.

** Department of Management Sciences, University of South Asia, Lahore, Pakistan. *** Noon Business School, University of Sargodha, Sargodha, Pakistan.
} 
of the country. Commercial banks, like many other organizations, are expected to generate profit through the effective and efficient utilization of inputs to produce maximum output. Commercial banks in each country help the central bank to achieve the economic targets. Moreover, the commercial banks keep the money as savings and helps to reallocate them as loans and investment in various financial markets.

After obtaining independence from Britain in 1947, the government realized their importance and established the central bank called the State Bank of Pakistan in 1948. Commercial banks have grown rapidly and gone through various developments over the years. The banking sector in Pakistan is comprised of 24 local and 16 foreign scheduled banks. According to State Bank of Pakistan, the total assets of commercial banks have increased from approximately 4.2 trillion PKR to 12.1 trillion PKR from 2006 to 2014 which shows an increase of $188 \%$. Bank deposits have increased from approximately 3.1 trillion PKR to 9.3 trillion PKR from 2006 to 2014 showing an increase of $200 \%$.

The assets of banks in Gross Domestic Product (GDP) of Pakistan over the period of 2004 to 2015 is shown in Figure 1. Their contribution gradually increased over the studied period except during the financial crises in the late 2000 s and early 2010s. This also confirms that the banking sector has a significant role in the overall development of Pakistan.

In the banking industry, CG significantly differs from the nonbanking firms due to the fact that banks are highly regulated by central banks (Macey, O'Hara 2003; Spong, Sullivan 2007; Andres, Vallelado 2008; Agoraki, Delis, Panagiotis 2009). The board and the management of the banks are responsible towards proprietors as well as to contributors, borrowers, investors, customers, bank and furthermore regulators (Ciancanelli et al., 2000; Pathan et al., 2007). According to Andres and Vallelado (2008), an additional system of governance is created by the strict regulations in banks. This greatly reduced the effectiveness of the CG in the banking industry and thus affects the bank's performance. In addition, the role of the banking industry is essential in ensuring the smoothness of monetary policy transmission in the developing countries because it provides the main source of financing to businesses. In this context, banks act as the assets transformers in transforming the short-term liabilities in the form of deposits into long-term loans. Therefore, the banking industry is highly leveraged and the mismatch resulted from the assets transformations may contribute to the failure of banks as well as distorting the creation of a sound financial system in the country. Furthermore, it is always a concern of the 
bank's regulators to prevent the effect of systemic risk in the banking industry. This is because the failure of one bank created a spillover effect to other banks and resulted in destabilization of the country's economic system (Calomiris 2007).

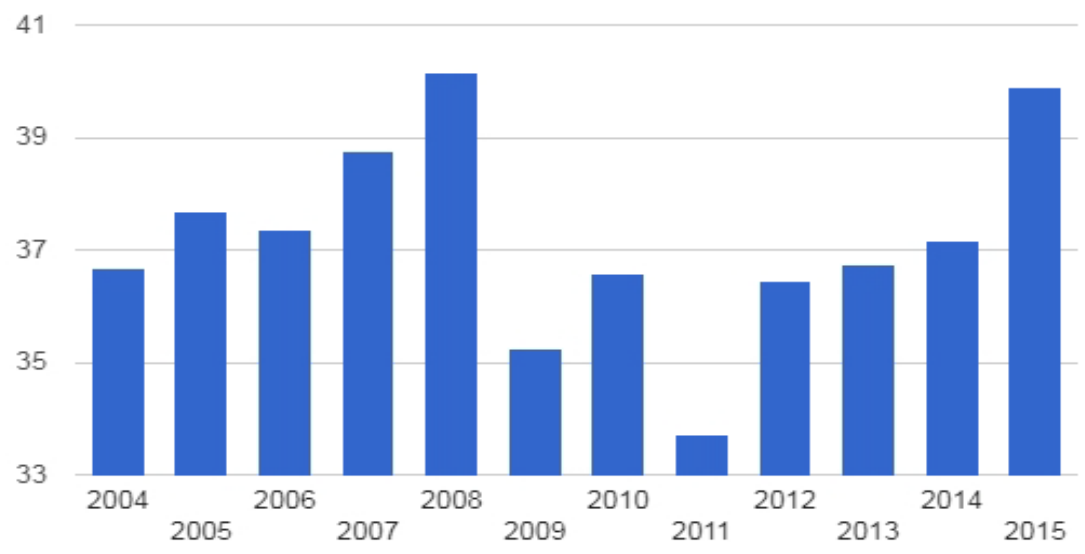

Fig.1: Assets of Commercial Banks to Gross Domestic Product (GDP) in Pakistan

Source: The Global Economy, The International Monetary Fund (IMF).

In this study, the Data Envelopment Analysis (DEA) approach has been used to measure bank efficiency. The panel data regression technique has been used to check the relationship between CG and the efficiency of commercial banks. The data of all 24 local scheduled banks listed on the Pakistan Stock Exchange has been gathered since the CG practices are implemented in the listed banks. This study is of a great value for the central bank (SBP), commercial bank managers, academics, and shareholders. By constructing a CG index, while including 38 variables (five sub-indexes) can provide future researchers with an alternative summary measure. This study has provided a picture of where commercial banks are currently stand in respect of following principles and codes introduced by the governing body. Moreover, this study will help the boards of directors to benchmark the performance of their banks against their competitors. Due to the requirement of this study we have only considered local commercial banks listed on Pakistan Stock Exchange (PSX) since CG regulations are only considered for listed firms. This study has considered all of the 24 scheduled local listed banks for analysis. 
The primary objective of this study is to find the level of CG in the commercial banks of Pakistan, whereas the second objective of this study is to examine the relationship between CG and efficiency (TE and CE) scores.

\section{LITERATURE REVIEW}

There are many studies in the empirical literature which have investigated the relationship between CG and efficiency. On the one hand, there are some studies which have found a positive relationship between $\mathrm{CG}$ and the performance of a firm. For instance, Khatab et al. (2011) used Tobin's Q, ROA, and ROE as performance indicators and found that the CG impacts positively the performance of the firms in Pakistan. Lin et al. (2009) used the number of board meetings and the percentage of outside directors as the main variables for the CG, and by applying the DEA approach found that CG has a positive effect on the efficiency of Chinese public listed manufacturing companies. Wang et al. (2007) has taken inside ownership, rights of voting and composition of the board as the variables for CG and applied the DEA approach to measuring technical and cost efficiency. It was found that CG has a positive relationship with the efficiency of Taiwan insurance companies. Kandukuri et al. (2015) found a positive association of CG with company performance measured by Tobin's Q in India. Another study by Bishnoi and Sh (2016) found the positive relationship of CG with the performance of foreign firms in India. Board size, board composition, board independence, and the conduct of the board and its committees were taken as variables for CG and the ratios of profit after tax to total assets and total income were taken as variables to measure performance. Asfandyar et al. (2013) took board size and leadership as CG variables and ROA and Tobin's $\mathrm{Q}$ as the financial performance variables and found the positive relationship between CG and financial performance of listed firms of Pakistan. Yasser et al. (2011) also suggested a positive relationship between CG and the financial performance of listed firms in Pakistan. Lee et al. (2013) showed the positive relationship between CG and efficiency of biotechnology and medical equipment industry in Taiwan. Abdoush (2017) suggested a significant relationship of CG with the performance of UK life and non-life insurance firms. He et al. (2015) investigated the impact of CG on the efficiency of listed manufacturing industry firms in China. The empirical results showed that CG is directly associated with the efficiency of listed manufacturing firms. Salim et al. (2016) also found a positive relationship between CG and the efficiency of eleven Australian banks. The data was taken for the period from 1999 to 2013.The two stage double-bootstrap DEA model was applied in this study. 
On the other hand, Makki and Lodhi (2013) did not depict the significant relationship between CG and the financial performance of Pakistani listed firms. For CG, the proportion of directors, the proportion of Non-Executive Directors (NEDs) on board, the dual role of CEO, director remuneration and the number of shareholders were taken. For company performance ROA and ROE were taken. Nanka-Bruce (2011) showed no positive relationship between CG and the efficiency of manufacturing firms in fifteen Western European countries. Board size and composition were taken as variables for CG and technical efficiency was calculated using the DEA approach to measure efficiency. Andries et al. (2018) investigated the relationship between CG and bank efficiency and for this purpose the data of banks were taken from seventeen countries of Central and Eastern Europe. The results showed that $C G$ is negatively associated with cost and technical efficiency.

Studies in Pakistan have just focused on traditional performance measures such as accounting and market-based measures as discussed earlier (Makki and Lodhi, 2013; Yasser et al. 2011). These traditional measures neglect various aspects to account for the influences of output price, input price and different exogenous business sector components due to which these traditional performance ratios do not depict the true performance. To measure the performance of financial institutions, academic research has progressively centered on another methodology, called frontier efficiency (or $\mathrm{X}$-efficiency) methodology in the last thirty years.

This study fills this gap by applying the frontier efficiency approach to measure efficiency scores. In addition, instead of considering one or two variables to measure $C G$, this study has prepared a $C G$ index which includes 38 variables of five sub-indexes including: board characteristics, audit committee, disclosure and transparency, remuneration committee and shareholders' rights.

\section{DATA AND METHODOLOGY}

The banking sector in Pakistan is comprised of local and foreign banks. Local banks include both public and private sector banks. For this study, data from local banks including five public and nineteen private sector banks were collected which are listed on the Pakistan Stock Exchange. These were the only listed commercial banks since the CG practices are followed by the listed firms in the only stock market of the country (PSX).

There are many studies which have tried to analyze the relationship of performance and $\mathrm{CG}$, but it is worth noting that most of these studies 
measured the performance with the traditional accounting (ROA and ROE, etc.) and market measures (Tobin's Q, etc.). However, these traditional performance ratios neglect to account for the influences of overall inputs and outputs which ultimately did not take into account the related exogenous business sector components, as eventually these traditional methods did not depict the overall performance.

To measure the performance of commercial banks, previous studies extensively used the frontier efficiency methodology for the last thirty years. Frontier efficiency works by measuring performance deviations from that of "best practice" firms. It shows how efficiently the management is utilizing resources and whether cost reduction of doing business is possible. Therefore, the study considered nonparametric Data Envelopment Analysis (DEA) for the measurement of the overall efficiency of the commercial banks in Pakistan. The technical and cost efficiencies are taken as the representatives of frontier efficiency since the technical efficiency indicates whether the management is able to produce optimally with the utilization of lower total inputs, whereas the technical efficiency is measured in terms of input prices. This is based on the optimization problem, therefore it does not require assumptions on the specification of the efficient frontier. The estimation of technical and cost efficiency from the DEA approach consists of two steps. Firstly, the technical efficiency of each decision-making unit (DMU) is computed following Banker et al. (1984); the model is presented in model 1.

In Model 1 and 2, $y_{r j}$ and $x_{i o}$ are the output and input of the $n$-th DMU, whereas $\lambda$ is the weight. $\theta$ is the efficiency score of DMU which is to be measured and by solving the non-parametric model, minimum $\theta_{0}$ is the efficiency score of that $\mathrm{DMU}_{0}$. The index $j$ specifies DMUs for $j=1, \ldots, N$. $y_{r j}$ is the $r$-th output of the $j$-th firm for $r=1, \ldots, R . x_{i j}$ indicates the $i$-th input of the $j$-th DMU for $i=1 \ldots \ldots . I$ (Mahlberg, 2000). The first constraint shows that output of the mentioned unit must be at least at the same level as the output of DMU. The second constraint states that the input usage of $\mathrm{DMU}_{0}$ must be higher than or at the same level as the input of the mentioned unit.

\section{Model 1: Technical Efficiency}

$\min \theta$

subject to

$$
\sum_{j=1}^{n} \lambda_{j} y_{r j} \geq y_{r 0}, \quad r=1,2,3, \ldots, s
$$




$$
\begin{array}{ll}
\sum_{j=1}^{n} \lambda_{j} x_{i j} \leq \theta_{i 0} x_{i 0}, & i=1,2,3, \ldots, n \\
\sum_{j=1}^{n} \lambda_{j}=1 & \\
\lambda_{j} \geq 0, & j=1,2,3, \ldots, n .
\end{array}
$$

(1) is the output constraint, and (2) is the output constrain in Model 1.

The second step is to compute the cost efficiency by following model.

\section{Model 2: Cost Efficiency}

$$
\min _{\lambda} w_{i 0} x_{i 0}
$$

subject to

$$
\begin{array}{ll}
\sum_{j=1}^{n} \lambda_{j} y_{r j} \geq y_{r 0}, & r=1,2,3, \ldots, s, \\
\sum_{j=1}^{n} \lambda_{j} x_{i j} \leq w_{i 0} x_{i 0}, & i=1,2,3, \ldots, n, \\
\sum_{j=1}^{n} \lambda_{j}=1, & \\
\lambda_{j} \geq 0, & j=1,2,3, \ldots, n .
\end{array}
$$

$w_{i}$ is a vector of input prices for $i$-th DMU and $x_{i}$ is the vector of cost minimization for input quantities for the $i$-th DMU given the price of the input vector $w_{i}$ and the $y_{i}$ is the output vector. In both equations, the third constraint introduces variable return to scale (VRS) into the model.

Variables for the inputs and outputs are not easy to identify in the banking industry since there are two main approaches for the selection of the inputs and outputs of the banking sector, which are the intermediation and production approach (Sealey and Lindley, 1977). The intermediation approach is best suited here because banks collect deposits and issue loans. For the purpose of this study, the choice of inputs and outputs is proposed by the choices provided in the previous studies (Sealey and Lindley, 1977; Ghosh et al. 2014). The study selected three inputs and three outputs. For the determinants of inputs, this research included: total deposits $\left(x_{1}\right)$, fixed assets 
$\left(x_{2}\right)$ and number of employees $\left(x_{3}\right)$, whereas total loans $\left(y_{1}\right)$, investments $\left(y_{2}\right)$ and total income $\left(y_{3}\right)$ are considered as outputs of the banks. The details of these variables are provided in Table 1 .

Technical efficiency and cost efficiency scores are considered as dependent variables in our Tobit regression. The data for the selected input, output variables, and CG were gathered from the annual reports of the banks. The CG is measured by constructing a CG index (CGI) by following the study of Munisi and Randøy (2013) which includes five dimensions of CG; board of directors, audit committee, disclosure and transparency, remuneration committee and shareholder's rights. These five sub-indexes have questions in them with the answer 'yes' or 'no' to check the degree of compliance of banks practicing with CG. These questions are the rules set by the code of CG which all banks have to follow for practicing good CG. The answers to these questions were taken from the annual financial statements of each bank taken in this study from 2005 to 2014. There are 38 questions in total divided into five sub-indexes appropriately, and their answers in the form of 'yes' or 'no' are taken from the annual financial statements of each bank yearly. The answer of 'yes' is given a numerical value 1 and 'no' is given 0 . All the values of 1 are added to form an overall index. The first subindex is regarding the board of directors, the second sub-index is about the audit committee, the third sub-index is regarding the disclosure and transparency, the fourth sub-index is about the remuneration committee, the fifth and the final sub-index is regarding shareholders' rights. To prepare the CG index, the equal-weighted approach is applied in this study by following Bebchuk et al. (2009) and Gompers et al. (2003).

The study has also considered various control variables suggested in empirical literature including: bank's size, liquidity, age, capital adequacy, and growth.

\section{Bank's size}

There is no consensus about the relationship between bank size and performance since the large size of the bank gives it advantages such as economies of scale and better access to customers, whereas they also face problems like lower growth and high fixed cost. Therefore, many studies reported a mixed relationship between the size of the firm and performance (Agrawal and Knoeber, 1996; Charles, et al., 1999; Nenova, 2003; Durnev and Kim, 2005; Short and Keasey, 1999). This study measured a bank's size by taking the natural $\log$ of total assets following Muth and Donaldson, (1998), Elsayed (2007) and Al-Matari et al. (2012). 


\section{Liquidity}

Jose et al (1996) declared that liquidity is important for a firm's survival. Liquidity is essential for an organization's smooth running but higher amounts of liquid assets increase the firm's opportunity cost (Fang et al., 2009). Liquidity ratio is measured as cash plus reserves divided by total assets following Pradhan and Shrestha (2016).

\section{Bank's age}

Company's age is an important control variable that has been utilized by various studies since it measures the firm's experience which comparatively gives an edge over others in terms of risk management, optimal utilization of resources and targeting the population; see Berger and Udell (1998). Bank's age is positively associated with bank's performance as age is positively correlated with experience which helps in achieving higher performance (DeYoung and Hasan, 1998; DeYoung et al., 1999). On the other hand, ElChaarani (2014) found no significant relationship between age and performance of the bank. Bank's age is measured by the number of years since the incorporation of the bank following Berger and Udell (1998), and Boone et al. (2007).

\section{Capital adequacy ratio (CAR)}

Capital adequacy ratio also affects the performance of the bank if we look at the past studies (DeYoung and Hasan, 1998). This ratio set by regulators indicates keeping a minimum capital requirement by the bank to properly manage their assets and to increase their performance (Unite and Sullivan, 2003; Naceur and Kandil, 2009). The bank performance can be enhanced by a satisfactory level of CAR ratio together with a viable and proficient bank administration and financing activities (Utama and Musa, 2011). This ratio is taken from the annual reports of banks.

\section{Growth in assets}

Assets are characterized as the economic resource of any firm that is expected to benefit the future operations of the firm. According to Salim and Yadav (2012), Soumadi and Hayajneh (2012) and Fairfield et al. (2003), growth in total assets is positively associated with the financial performance. The growth in total assets indicates the percentage increase of investment in 
assets by a bank. We measured growth as $\left(G T A_{T}-G T A_{T-1}\right) / G T A_{T-1}$ following Fairfield et al. (2003). The variables with measurements are described in Table 2.

By concluding the above discussion, this study provided the following models in equations 4 and 5 to investigate the relationship of the CG index with efficiency.

\subsection{Tobit regression equations}

$$
\begin{aligned}
& \mathrm{TE}_{\mathrm{it}}=\beta_{0}+\beta_{1} C G I_{i t}+\beta_{2} \text { SSIZE }_{i t}+\beta_{3} A G E_{i t}+ \\
& \beta_{4} \text { IIQUIDITY }_{i t}+\beta_{5} C_{2} R_{i t}+\beta_{6} G R W T H_{i t}+e_{i t}, \\
& \mathrm{CE}_{\mathrm{it}}=\beta_{0}+\beta_{1} C G I_{i t}+\beta_{2} \text { BSIZE }_{i t}+\beta_{3} A G E_{i t}+ \\
& \beta_{4} \text { IIQUIDITY }_{i t}+\beta_{5} \text { CAR }_{i t}+\beta_{6} \text { GRWTH }_{i t}+e_{i t}
\end{aligned}
$$

where $i=1, \ldots, 24$ commercial banks, $t=2005, \ldots, 2014$.

This study applied the Tobit regression technique. The Tobit model is a measurable model proposed by James Tobin (1958) and is used widely in the existing literature, e.g. Drakos and Bekiris (2010), Lee et al. (2013) and Afza and Asghar (2017), to check the relationship between CG and efficiency.

\section{EMPIRICAL RESULTS}

Loans, investments, and income of commercial banks have increased by $158 \%, 663 \%$ and $332 \%$, respectively, whereas fixed assets, deposits and number of employees increased by $320 \%, 270 \%$ and $60 \%$, respectively over the studied period (see Table 2). The mean and standard deviation of CG sub-indices presented in Table 3 show that in the early years of study, banks were reluctant to practice good CG, however with time they improved their overall index since the CG index score increased from $33 \%$ to $88 \%$ on average over that period. Descriptive statistics of DEA inputs and outputs, CG sub-indexes and control variables are presented in Tables 3 and 4.

\subsection{CG index results}

The first research objective of this research is to check the level of CG and for this reason the score card or CG index of commercial banks is given in Table 4. It can be seen that in 2005 very few banks were implementing good CG practices, since in 2005 the Al-Falah bank was on top with a CG 
score of 54.82, the KASB bank was second with a CG score of 50.87. Furthermore, only four banks: the Askari bank, the Al Habib bank, the NIB and the Meezan bank had a CG score above 40. In 2010 all the banks improved their CG score with no bank showed their CG score as less than 60. In addition, four banks (the MCB, the Askari Bank, the United Bank and the Meezan bank) showed significant improvement with CG scores of 94 , 92, 93 and 92, respectively. The CG score of all banks further improved in the later years of study. In 2014 the leading bank regarding the good practice of CG was the MCB bank with a CG score of 98.9. In addition, most of the banks had a CG score of 80 or above with the exception of Sindh and the National Bank of Pakistan. These CG scores suggest that a large number of the commercial banks were slower during 2005 to 2008 in implementing good CG practices which may be because of the fact that the idea of CG was new to corporations in Pakistan. However, after 2008 banks understood CG's significance and therefore they raised their CG practices which eventually enhanced their CG score since the majority of the banks in 2014 had a CG score of above 80 . The score card of CG is given in Table 5.

\subsection{Tobit results}

The Tobit regression was applied to investigate the relationship of CG scores with the technical and cost efficiency scores. CG has a positive relationship with technical and cost efficiency and these results are in line with the study of Nanka-Bruce (2011), Tanna et al. (2008), Wang et al. (2007) and Lee et al.(2013). The board of directors was found positively and significantly related with both cost efficiency and technical efficiency; this result is consistent with Huang, Lai, McNamara, and Wang (2011), Lin et al. (2009) and Jegede et al. (2013). The audit committee was found positively and significantly related with cost efficiency and this result is consistent with Yasser et al. (2011). However, the study failed to find any significant relationship between the audit committee and technical efficiency Ahmad et al. (2014) also found same results. In the same way disclosure and transparency also showed a positive relationship with cost and technical efficiency, and this result is consistent with Javid and Iqbal (2014) and Akingunola et al. (2013). Remuneration committee was found positively and significantly related to both cost and technical efficiency, consistently with Windsor and Cybinski (2009). The shareholders' rights also showed a positive relationship between cost efficiency and technical efficiency and 
this result is consistent with Chugh et al. (2010). These results are taken from performance, since there is a lack of literature on efficiency. The Tobit regression results are shown in Table 6.

\section{CONCLUSION}

In the present era, many financial scandals have shaken investors' faith in banks as well as in capital markets, hence investors are comparatively giving more importance to good CG practices than ever before, since it promotes accountability and transparency. CG combats with challenges like: unprofessional conduct, fraud and forgeries, weak internal control measures and non-implementation of internationally acceptable accounting principles. These aforementioned problems affect the relative performance of the banks which lead to inefficiency.

This study used the frontier efficiency technique to measure the efficiency of commercial banks and then analyze the relationship of CG with the efficiency of commercial banks. In addition, this study has constructed an index of $\mathrm{CG}$ for commercial banks and further decomposed this index into: board of directors, audit committee, disclosure and transparency, remuneration committee and shareholders' rights for a more comprehensive analysis.

The study suggests that CG is positively related to both technical and cost efficiency thus affirming agency theory hypothesis which states that there may be a source of conflict between the agents and the principals when they have different interests. The further findings on the relationship between sub-indexes of CG and efficiency also affirmed the same results.

The empirical results may encourage further study to examine the relationship of each variable of the sub-index with efficiency or may enhance the sample size by adding other financial institutions. They can also consider other countries for a comparative analysis.

\section{REFERENCES}

Abdoush, T., Corporate Governance, firm performance, and efficiency: three empirical analyses of the UK insurance industry, p.258. University of Southampton, Southampton Business School, Doctoral Thesis, 2017.

Adnan, M. A., Htay, S. N. N., Rashid, H. M. A., Meera, A. K. M. M., A Panel Data Analysis on the Relationship between Corporate Governance and Bank Efficiency, "Journal of Accounting, Finance, and Economics", 1(1), pp.1-15, 2011. 
Afza, T., Asghar, M. J. K. A., Efficiency of Commercial Banks in Pakistan: Application of SFA and Value Added Approach, "Argumenta Oeconomica", 1(38), pp.195-220, 2017.

Agrawal, A., Knoeber, C. R., Firm Performance and Mechanisms to Control Agency Problems between Managers and Shareholders, "The Journal of Financial and Quantitative Analysis", 31(3), pp.377-397, 1996.

Al-Matri, Y., Al-Swidi, A. K., Fadzil, F. H. B. F. H., Al-Matari, E. M., Board of Directors, Audit Committee Characteristics, and Performance of Saudi Arabia Listed Companies, "International Review of Management and Marketing", 2(4), pp.241-251, 2012.

Andries, A. M., Capraru, B., Nistor, S., Corporate Governance and Efficiency in Banking: Evidence from Emerging Economies, “Applied Economics”, pp.1-21, 2018.

Asfandyar, Aziz, U., Butt, A. A., Tasawar, A., Does Board Mechanism Matter in Augmenting the Financial Performance of Firms in Pakistan?, "Science International", 25(3), p.627, 2013.

Barnor, C., Odonkor, T., Capital Adequacy and the Performance of Ghanaian Banks, "Journal of Business Research", 6(1-2), pp.105-117, 2012.

Berger, A. N., Humphrey, D. B., The efficiency of Financial Institutions: International Survey and Directions for Future Research, "European Journal of Operational Research", 98, pp. 175-212, 1997.

Berger, A. N., Udell, G. F., The Economics of Small Business Finance: The Roles of Private Equity and Debt Markets in the Financial Growth Cycle, "Journal of Banking and Finance", Elsevier, 22(6-8), pp.613-673, 1998.

Bishnoi, T. R., Devi, S., Corporate Governance and Performance of Foreign Firms in India, "Indian Journal of Corporate Governance", 8 (2), pp.137-152, 2016.

Boone, A. L., Field, L. C., Karpoff, J., Raheja, C. G., The Determinants of Corporate Board Size and Composition: An Empirical Analysis, "Journal of Financial Economics", 85, pp.65-101, 2007.

Charles, P. H., Hubbard, R., Palia, D., Understanding the Determinants of Managerial Ownership and the Link between Ownership and Performance, "Journal of Financial Economics", 53, pp.353-384, 1999.

Chugh, L. C., Meador, J. W., Meador, M. W., Corporate Governance: Shareholder Rights And Firm Performance, "Journal of Business \& Economics Research" (JBER), 8(9), 2010.

Daines, R., Does Delaware Law Improve Firm Value?, "Journal of Financial Economics”, 62, pp. 525-558, 2001.

DeYoung, R., Hasan, I., The performance of the Novo bank commercial bank: a profit efficiency approach, "Journal of Banking and Finance" 22, pp. 565-587, 1998.

DeYoung, R., Golberg, G. L., White, J. L., Youth, adolescence, and maturity of banks: credit availability to small business in an era of banking consolidation, "Journal of Banking and Finance" 23, pp. 463-492, 1999.

Durnev, A., Kim, E. H., To Steal or Not to Steal: Firm Attributes, Legal Environment, and Valuation, "The Journal of Finance", 60(3), pp. 1461-1493, 2005.

El-Chaarani, H., The Impact of Corporate Governance on the Performance of Lebanese Banks, "The International Journal of Business and Finance Research", 8(5), pp. 35-46, 2014. 
Eling, M., Luhnen, M., Frontier Efficiency Methodologies to Measure Performance in the Insurance Industry: Overview and New Empirical Evidence, Working Paper No. 56, Institute of Insurance Economics, University of St. Gallen, Switzerland, 2008.

Elsayed, K., Does CEO Duality Really Affect Corporate Performance? Corporate Governance: An International Review, "Wiley Blackwell”, 15(6), pp. 1203-1214, 2007.

Fairfield, P. M., Whisenant, J. S., Yohn, T. L., Accrued Earnings and Growth: Implications for Future Profitability and Market Mispricing, "The Accounting Review", 78, pp. 353371, 2003.

Fang, V. W., Noe, T. H., Tice, S., Stock market liquidity and firm value, "Journal of Financial Economics", 94(1), pp. 150-169, 2009.

He, Y., Chiu, Y., Zhang, B., The impact of Corporate Governance on state-owned and nonstate-owned firms efficiency in China, "The North American Journal of Economics and Finance", 33, pp. 252-277, 2015.

Huang, L., Lai, G. C., McNamara, M., Wang, J., Corporate Governance and Efficiency: Evidence from U.S. Property-Liability Insurance Industry, "The Journal of Risk and Insurance", 78(3), pp. 519-550, 2011.

Javid, A. Y., Iqbal, R., Ownership Concentration, Corporate Governance, and Firm Performance: Evidence from Pakistan, "The Pakistan Development Review", 47(4), pp. 643-659, 2008.

Jegede, C. A., Akinlabi, H. B., Soyebo, Y. A., Corporate Governance Efficiency and Bank Performance in Nigeria, "World Journal of Social Sciences", 3(1), pp. 178-192, 2013.

Jose, M. L., Lancaster, C., Stevens, J. L., Corporate return and cash conversion cycles, "Journal of Economics and Finance", 20, pp. 33-46, 1996.

Kandukuri, R. L., Memdani L., Babu, P. R., Effect of Corporate Governance on Firm Performance - A Study of Selected Indian Listed Companies [in:] Kensinger, W. J. (ed.), Overlaps of Private Sector with Public Sector around the Globe (Research in Finance, Volume 31), pp.47-64. Emerald Group Publishing Limited, 2015.

Khatab, H., Masood, M., Zaman, K., Saleem, S. Saeed, B., Corporate Governance and Firm Performance: A Case study of Karachi Stock Market, "International Journal of Trade, Economics, and Finance", 2(1), 2011.

Kirkpatrick, G., The Corporate Governance lessons from the financial crisis, "Financial Market Trends - OECD Journal", 2009/1.

Lee, Y., Huang, Y., Hsu, S., Hung, C., Measuring the Efficiency and the Effect of CG on the Biotechnology and Medical Equipment Industries in Taiwan, "International Journal of Economics and Financial Issues", 3(2), pp. 662-672, 2013.

Lin, C., Ma, Y., Su, D., Corporate Governance and Firm Efficiency: Evidence from China's Publicly Listed Firms, "Managerial and Decision Economics", 30, pp. 193-209, 2009.

Mahlberg, B., Url, T., The Transition to the Single Market in the German Insurance Industry. Working paper No. 131, Austrian Institute of Economic Research, Vienna 2000.

Munisi, G., Randøy, T., Corporate Governance and company performance across SubSaharan African countries, "Journal of Economics and Business", 70, pp. 92-110, 2013.

Makki, M. A., Lodhi, S. A., Impact of Corporate Governance on Financial Performance, "Pakistan Journal of Social Sciences", 33(2), pp. 265-280, 2013. 
Muth, M., Donaldson, L., Stewardship Theory and Board Structure: A Contingency Approach, "Corporate Governance: An International Review", 6(1), pp. 5-28, 1998.

Naceur, S. B., Kandil, M., The impact of capital requirements on banks cost of intermediation and performance: the case of Egypt, "Journal of Economics and Business", 61, pp. 70-89, 2009.

Nanka-Bruce, D., Corporate Governance Mechanisms and Firm Efficiency, "International Journal of Business and Management”, 6(5), pp. 28-40, 2011.

Nenova, T., The value of corporate voting rights and control: a cross-country analysis, "Journal of Financial Economics", 68, pp. 325-351, 2003.

Salim, M, Yadav, R., Capital Structure and Firm Performance: Evidence from Malaysian Listed Companies, "Procedia - Social and Behavioral Sciences", 65, pp. 156-166, 2012.

Salim, R., Arjomandi, A. Seufert, Heinz, J., Does Corporate Governance affect Australian banks' performance?, "Journal of International Financial Markets, Institutions and Money", 43, pp. 113-125, 2016.

Sanusi, J. O., Embracing good Corporate Governance practices in Nigeria. 19th annual directors seminar organized by the Financial Institute Training Centre, Abuja 2003.

Sealey, C. W., Lindley J. T., Inputs, Outputs and a Theory of Production and Cost at Depository Financial Institutions, "The Journal of Finance” 32, pp. 1251-1266, 1977.

Short, H., Keasey, K., Managerial ownership and the performance of firms: Evidence from the UK, "Journal of Corporate Finance", 5(1), pp. 79-101, 1999.

Soumadi, H., Capital structure and Corporate performance empirical study on the public Jordanian shareholdings firms listed in the Amman stock market, "European Scientific Journal", October edition, 8(22), pp. 1857-7881, 2012.

State Bank of Pakistan, List of Scheduled and Co-operative banks in Pakistan (Appendix III). Karachi, Pakistan, 2017.

Tanna, S., Pasiouras, F., Nnadi, M., The Effect of Board Size and Composition on the Efficiency of UK Banks, "International Journal of the Economics of Business", 2011, 18 (3), pp. 441-462, 2008.

Utama, C. A., Musa, H., The Causality between Corporate Governance Practice and Bank Performance: Empirical Evidence from Indonesia, "Gadjah Mada International Journal of Business", 13(3), 2011.

Unite, A. A., Sullivan, M. J., The effect of foreign entry and ownership structure on the Philippine domestic banking market, "Journal of Banking \& Finance", 27(12), pp. 23232345, 2003.

Wang, J. L., Jeng, V., Peng, J. L., The Impact of Corporate Governance Structure On The Efficiency Performance Of Insurance Companies In Taiwan, "The Geneva Papers", 32, pp. 264-282, 2007.

Windsor, C. A., Cybinski, P. J., Size Matters: The Link between CEO Remuneration, Firm Size and Firm Performance Moderated by Remuneration Committee Independence. Griffith University Business School Discussion Paper Economics, 2009.

Yasser, Q. R., Entebang, H., Mansor, S. A. (2011). Corporate Governance and firm performance in Pakistan: The case of Karachi Stock Exchange (KSE)-30, "Journal of Economics and International Finance", 3(8), pp. 482-491, 2011.

Received: September 2017, revised: July 2018 


\section{APPENDIX}

Table 1

Variables for Data Envelopment Analysis

\begin{tabular}{c|c|c}
\hline Inputs & Input prices & Outputs \\
\hline Deposits $\left(x_{1}\right)$ & Interest (Interest expense / Deposits) $\left(w_{1}\right)$ & $\begin{array}{c}\text { Total loans } \\
\left(y_{1}\right)\end{array}$ \\
\hline Fixed assets $\left(x_{2}\right)$ & Depreciation $\left(w_{2}\right)$ & $\begin{array}{c}\text { Investments } \\
\left(y_{2}\right)\end{array}$ \\
\hline $\begin{array}{c}\text { Number of } \\
\text { employees }\left(x_{3}\right)\end{array}$ & $\begin{array}{c}\text { Employee expense per capita (Total employee } \\
\text { expense / Number of employees) }\left(w_{3}\right)\end{array}$ & $\begin{array}{c}\text { Total income } \\
\left(y_{3}\right)\end{array}$ \\
\hline
\end{tabular}

Source: authors' own selection.

Table 2

Dependent, independent and control variables

\begin{tabular}{|c|c|c|}
\hline Symbol & Variable name & Measure \\
\hline \multicolumn{3}{|c|}{ Dependent variables } \\
\hline$T E$ & Technical efficiency & $\begin{array}{l}\text { DEA efficiency } \\
\text { scores }\end{array}$ \\
\hline$C E$ & Cost efficiency & $\begin{array}{l}\text { DEA efficiency } \\
\text { scores }\end{array}$ \\
\hline \multicolumn{3}{|c|}{ Independent variable } \\
\hline$C G I$ & $\begin{array}{l}\text { Corporate Governance index (board of directors, audit } \\
\text { committee, disclosure and transparency, remuneration } \\
\text { committee and shareholders' rights) }\end{array}$ & $\begin{array}{l}\text { Index in constructed } \\
\text { using equal weight } \\
\text { index }\end{array}$ \\
\hline \multicolumn{3}{|c|}{ Control variables } \\
\hline SIZE & Bank size & Log of total assets \\
\hline$A G E$ & Bank age & Age of bank \\
\hline LIQUIDITY & Liquidity ratio & $\begin{array}{l}\text { (Cash + reserves) / } \\
\text { Total assets }\end{array}$ \\
\hline$C A R$ & Capital adequacy ratio & $\begin{array}{l}\text { Capital / Risk- } \\
\text { weighted assets }\end{array}$ \\
\hline GRWTH & Growth in total assets & $\begin{array}{l}\left(\mathrm{GTA}_{\mathrm{T}}-\mathrm{GTA}_{\mathrm{T}-1}\right) / \\
\mathrm{GTA}_{\mathrm{T}-1}\end{array}$ \\
\hline
\end{tabular}

Source: authors' own selection. 
THE CORPORATE GOVERNANCE AND EFFICIENCY OF COMMERCIAL BANKS IN PAKISTAN [...] 185

Table 3

Descriptive statistics of DEA inputs and outputs (in PKR, M - million, $\mathrm{K}$ - thousand)

\begin{tabular}{|c|c|c|c|c|c|c|c|c|c|c|c|}
\hline \multicolumn{2}{|c|}{ Variables } & 2005 & 2006 & 2007 & 2008 & 2009 & 2010 & 2011 & 2012 & 2013 & 2014 \\
\hline \multirow{4}{*}{ 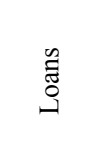 } & Mean & $89 \mathrm{M}$ & $96 \mathrm{M}$ & $110 \mathrm{M}$ & $133 \mathrm{M}$ & $141 \mathrm{M}$ & $152 \mathrm{M}$ & $149 \mathrm{M}$ & $168 \mathrm{M}$ & $181 \mathrm{M}$ & $183 \mathrm{M}$ \\
\hline & $D$ & $2 \mathrm{M}$ & $107 \mathrm{M}$ & $115 \mathrm{M}$ & $142 \mathrm{M}$ & $153 \mathrm{M}$ & $152 \mathrm{M}$ & $156 \mathrm{M}$ & $181 \mathrm{M}$ & $184 \mathrm{M}$ & $181 \mathrm{M}$ \\
\hline & Min & $2 \mathrm{M}$ & $1 \mathrm{M}$ & $3 \mathrm{M}$ & $3 \mathrm{M}$ & $3 \mathrm{M}$ & $7 \mathrm{M}$ & $7 \mathrm{M}$ & $9 \mathrm{M}$ & $9 \mathrm{M}$ & $8 \mathrm{M}$ \\
\hline & Max & $08 \mathrm{M}$ & $355 \mathrm{M}$ & $381 \mathrm{M}$ & $460 \mathrm{M}$ & $531 \mathrm{M}$ & $540 \mathrm{M}$ & $596 \mathrm{M}$ & $734 \mathrm{M}$ & $713 \mathrm{M}$ & $728 \mathrm{M}$ \\
\hline \multirow{4}{*}{ 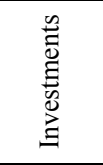 } & Mean & $35 \mathrm{M}$ & $32 \mathrm{M}$ & $52 \mathrm{M}$ & $44 \mathrm{M}$ & $69 \mathrm{M}$ & $89 \mathrm{M}$ & $122 \mathrm{M}$ & $162 \mathrm{M}$ & $174 \mathrm{M}$ & $213 \mathrm{M}$ \\
\hline & SD & $40 \mathrm{M}$ & $37 \mathrm{M}$ & $57 \mathrm{M}$ & $46 \mathrm{M}$ & $66 \mathrm{M}$ & $87 \mathrm{M}$ & $120 \mathrm{M}$ & $179 \mathrm{M}$ & $198 \mathrm{M}$ & $226 \mathrm{M}$ \\
\hline & Min & $2 \mathrm{M}$ & $0.4 \mathrm{M}$ & $3 \mathrm{M}$ & $2 \mathrm{M}$ & $4 \mathrm{M}$ & $3 \mathrm{M}$ & $5 \mathrm{M}$ & $7 \mathrm{M}$ & $7 \mathrm{M}$ & $7 \mathrm{M}$ \\
\hline & Max & $57 \mathrm{M}$ & $140 \mathrm{M}$ & $211 \mathrm{M}$ & $171 \mathrm{M}$ & $218 \mathrm{M}$ & $301 \mathrm{M}$ & $419 \mathrm{M}$ & $797 \mathrm{M}$ & $826 \mathrm{M}$ & $898 \mathrm{M}$ \\
\hline \multirow{4}{*}{ 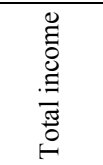 } & Mean & $13 \mathrm{M}$ & $16 \mathrm{M}$ & $20 \mathrm{M}$ & $25 \mathrm{M}$ & $30 \mathrm{M}$ & $32 \mathrm{M}$ & $36 \mathrm{M}$ & $40 \mathrm{M}$ & $40 \mathrm{M}$ & $43 \mathrm{M}$ \\
\hline & SD & $3 \mathrm{M}$ & $17 \mathrm{M}$ & $20 \mathrm{M}$ & $24 \mathrm{M}$ & $30 \mathrm{M}$ & $31 \mathrm{M}$ & $36 \mathrm{M}$ & $39 \mathrm{M}$ & $40 \mathrm{M}$ & $41 \mathrm{M}$ \\
\hline & Min & $1 \mathrm{M}$ & $0.1 \mathrm{M}$ & $1 \mathrm{M}$ & $1 \mathrm{M}$ & $1 \mathrm{M}$ & $1 \mathrm{M}$ & $2 \mathrm{M}$ & $2 \mathrm{M}$ & $2 \mathrm{M}$ & $2 \mathrm{M}$ \\
\hline & Max & $43 \mathrm{M}$ & $56 \mathrm{M}$ & $64 \mathrm{M}$ & $77 \mathrm{M}$ & $97 \mathrm{M}$ & $107 \mathrm{M}$ & $116 \mathrm{M}$ & $133 \mathrm{M}$ & $140 \mathrm{M}$ & $156 \mathrm{M}$ \\
\hline \multirow{4}{*}{ 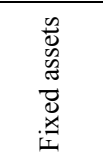 } & Mean & $3 \mathrm{M}$ & $3 \mathrm{M}$ & $7 \mathrm{M}$ & $7 \mathrm{M}$ & $7 \mathrm{M}$ & $8 \mathrm{M}$ & $9 \mathrm{M}$ & $9 \mathrm{M}$ & $10 \mathrm{M}$ & $10 \mathrm{M}$ \\
\hline & SD & $3 \mathrm{M}$ & $4 \mathrm{M}$ & $9 \mathrm{M}$ & $9 \mathrm{M}$ & $7 \mathrm{M}$ & $8 \mathrm{M}$ & $8 \mathrm{M}$ & $9 \mathrm{M}$ & $10 \mathrm{M}$ & $11 \mathrm{M}$ \\
\hline & Min & $08 \mathrm{M}$ & $0.14 \mathrm{M}$ & $15 \mathrm{M}$ & $17 \mathrm{M}$ & $0.2 \mathrm{M}$ & $0.19 \mathrm{M}$ & $.23 \mathrm{M}$ & $0.24 \mathrm{M}$ & $0.29 \mathrm{M}$ & $0.38 \mathrm{M}$ \\
\hline & Max & $11 \mathrm{M}$ & $12 \mathrm{M}$ & $31 \mathrm{M}$ & $33 \mathrm{M}$ & $25 \mathrm{M}$ & $28 \mathrm{M}$ & $29 \mathrm{M}$ & $30 \mathrm{M}$ & $35 \mathrm{M}$ & $32 \mathrm{M}$ \\
\hline \multirow{4}{*}{ 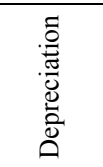 } & Mean & $215 \mathrm{~K}$ & $229 \mathrm{~K}$ & $295 \mathrm{~K}$ & $395 \mathrm{~K}$ & $503 \mathrm{~K}$ & $558 \mathrm{~K}$ & $613 \mathrm{~K}$ & $636 \mathrm{~K}$ & $705 \mathrm{~K}$ & $776 \mathrm{~K}$ \\
\hline & SD & $217 \mathrm{~K}$ & $221 \mathrm{~K}$ & $288 \mathrm{~K}$ & $354 \mathrm{~K}$ & $401 \mathrm{~K}$ & $430 \mathrm{~K}$ & $479 \mathrm{~K}$ & $484 \mathrm{~K}$ & $564 \mathrm{~K}$ & $652 \mathrm{~K}$ \\
\hline & Min & $12 \mathrm{~K}$ & $6 \mathrm{~K}$ & $16 \mathrm{~K}$ & $15 \mathrm{~K}$ & $20 \mathrm{~K}$ & $20 \mathrm{~K}$ & $25 \mathrm{~K}$ & $25 \mathrm{~K}$ & $73 \mathrm{~K}$ & $65 \mathrm{~K}$ \\
\hline & Max & $705 \mathrm{~K}$ & $743 \mathrm{~K}$ & $957 \mathrm{~K}$ & $9 \mathrm{~K}$ & $1468 \mathrm{~K}$ & $\mathrm{~K}$ & $1 \mathrm{~K}$ & $1506 \mathrm{~K}$ & $1699 \mathrm{~K}$ & $2037 \mathrm{~K}$ \\
\hline \multirow{4}{*}{ 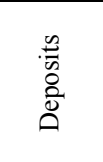 } & Mean & $28 \mathrm{M}$ & $126 \mathrm{M}$ & $155 \mathrm{M}$ & $169 \mathrm{M}$ & $194 \mathrm{M}$ & $226 \mathrm{M}$ & $251 \mathrm{M}$ & $295 \mathrm{M}$ & $337 \mathrm{M}$ & $374 \mathrm{M}$ \\
\hline & SD & $138 \mathrm{M}$ & $143 \mathrm{M}$ & $165 \mathrm{M}$ & $184 \mathrm{M}$ & $208 \mathrm{M}$ & $231 \mathrm{M}$ & $266 \mathrm{M}$ & $320 \mathrm{M}$ & $362 \mathrm{M}$ & $393 \mathrm{M}$ \\
\hline & Min & $6 \mathrm{M}$ & $2 \mathrm{M}$ & $8 \mathrm{M}$ & $6 \mathrm{M}$ & $9 \mathrm{M}$ & $10 \mathrm{M}$ & $14 \mathrm{M}$ & $19 \mathrm{M}$ & $18 \mathrm{M}$ & $13 \mathrm{M}$ \\
\hline & Max & $62 \mathrm{M}$ & $502 \mathrm{M}$ & $592 \mathrm{M}$ & $625 \mathrm{M}$ & $728 \mathrm{M}$ & $832 \mathrm{M}$ & $934 \mathrm{M}$ & $1215 \mathrm{M}$ & $1401 \mathrm{M}$ & $1525 \mathrm{M}$ \\
\hline \multirow{4}{*}{ 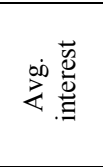 } & Mean & 0.03 & 0.05 & 0.06 & 0.08 & 0.08 & 0.08 & 0.08 & 0.07 & 0.06 & 0.06 \\
\hline & SD & 0.01 & 0.03 & 0.02 & 0.03 & 0.03 & 0.02 & 0.02 & 0.02 & 0.02 & 0.02 \\
\hline & Min & .01 & 0002 & 0.03 & 0.04 & 0.04 & 0.04 & 0.05 & 0.05 & 0.04 & 0.03 \\
\hline & $\operatorname{Max}$ & 0.07 & 0.10 & 0.10 & 0.13 & 0.14 & 0.14 & 0.14 & 0.13 & 0.09 & 0.11 \\
\hline \multirow{4}{*}{ 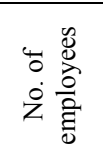 } & Mean & 4418 & 4187 & 4576 & 4946 & 4905 & 5066 & 5105 & 5179 & 5317 & 5581 \\
\hline & SD & 4990 & 4774 & 4666 & 4730 & 4569 & 4576 & 4718 & 4584 & 4514 & 4595 \\
\hline & Min & 495 & 18 & 319 & 540 & 569 & 585 & 462 & 641 & 614 & 573 \\
\hline & Max & 16314 & 14572 & 14552 & 15441 & 16248 & 16457 & 16924 & 16921 & 16619 & 16190 \\
\hline \multirow{4}{*}{ 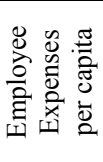 } & Mean & 359 & 388 & 468 & 546 & 615 & 654 & 721 & 792 & 837 & 901 \\
\hline & SD & 110 & 143 & 151 & 152 & 208 & 212 & 246 & 246 & 251 & 318 \\
\hline & Min & 202 & 42 & 192 & 282 & 353 & 387 & 394 & 407 & 440 & 520 \\
\hline & Max & 639 & 626 & 816 & 835 & 950 & 1034 & 1421 & 1391 & 1353 & 1803 \\
\hline \multicolumn{2}{|c|}{$\begin{array}{l}\text { No of banks } \\
\text { (observations) }\end{array}$} & 19 & 23 & 23 & 23 & 23 & 23 & 24 & 24 & 24 & 24 \\
\hline
\end{tabular}

Source: author own calculations. 
Table 4

Descriptive statistics of Corporate Governance sub-indices and control variables

\begin{tabular}{|c|c|c|c|c|c|c|c|c|c|c|c|}
\hline \multicolumn{2}{|c|}{ Sub-indices } & 2005 & 2006 & 2007 & 2008 & 2009 & 2010 & 2011 & 2012 & 2013 & 2014 \\
\hline \multirow{4}{*}{$\begin{array}{l}\text { Board of } \\
\text { directors }\end{array}$} & Mean & 6.98 & 9.69 & 11.77 & 12.81 & 15.31 & 16.25 & 17.19 & 17.92 & 18.23 & 18.23 \\
\hline & SD & 5.05 & 4.38 & 5.03 & 5.53 & 3.99 & 4.04 & 2.13 & 1.90 & 1.73 & 1.73 \\
\hline & Min. & 0 & 0 & 0 & 0 & 0 & 0 & 12.5 & 15 & 15 & 15 \\
\hline & Max. & 15 & 15 & 20 & 20 & 20 & 20 & 20 & 20 & 20 & 20 \\
\hline \multirow{4}{*}{$\begin{array}{l}\text { Audit } \\
\text { committee }\end{array}$} & Mean & 9.17 & 13.33 & 15.00 & 16.17 & 17.33 & 18.33 & \begin{tabular}{|l|}
18.67 \\
\end{tabular} & 18.83 & 19.00 & 19.33 \\
\hline & SD & 8.04 & 7.04 & 7.10 & 6.51 & 5.10 & 4.24 & 2.81 & \begin{tabular}{|l|}
2.20 \\
\end{tabular} & 2.13 & 1.93 \\
\hline & Min. & 0 & 0 & 0 & 0 & 0 & 0 & 8 & 12 & 12 & 12 \\
\hline & Max. & 20 & 20 & 20 & 20 & 20 & 20 & 20 & 20 & 20 & 20 \\
\hline \multirow{4}{*}{$\begin{array}{l}\text { Disclosure } \\
\text { and } \\
\text { transparency }\end{array}$} & Mean & 4.78 & 6.36 & 9.04 & 10.96 & 12.68 & 13.55 & 14.25 & 14.91 & 15.18 & 15.75 \\
\hline & SD. & 3.48 & 3.22 & 2.94 & 3.30 & 3.32 & 3.23 & 2.48 & 2.66 & 2.84 & 2.14 \\
\hline & Min. & 0 & 0 & 0 & 0 & 0 & 0 & 5.26 & \begin{tabular}{|l}
7.37 \\
\end{tabular} & 8.42 & 11.58 \\
\hline & Max. & 10.53 & 12.63 & 13.68 & 16.84 & 16.84 & 16.84 & \begin{tabular}{|l|}
17.89 \\
\end{tabular} & 18.95 & 20 & 20 \\
\hline \multirow{4}{*}{$\begin{array}{l}\text { Remuneration } \\
\text { committee }\end{array}$} & Mean & 0.83 & 0.83 & 1.88 & 4.17 & 7.08 & 12.29 & \begin{tabular}{|l|}
11.88 \\
\end{tabular} & \begin{tabular}{|l}
12.92 \\
\end{tabular} & 15.21 & 15.63 \\
\hline & SD & 2.41 & 2.41 & 4.62 & 6.86 & \begin{tabular}{|l|}
7.79 \\
\end{tabular} & 8.07 & 8.18 & \begin{tabular}{|l|}
7.79 \\
\end{tabular} & 5.99 & 5.95 \\
\hline & Min. & 0 & 0 & 0 & 0 & 0 & 0 & 0 & 0 & 0 & 0 \\
\hline & Max. & 10 & 10 & 20 & 20 & 20 & 20 & 20 & 20 & 20 & 20 \\
\hline \multirow{4}{*}{$\begin{array}{l}\text { Shareholders' } \\
\text { rights }\end{array}$} & Mean & 4.17 & 5.42 & 6.67 & 9.17 & 11.25 & 16.67 & 15.83 & 18.75 & 18.33 & 19.58 \\
\hline & SD & 5.04 & 5.88 & 6.37 & 7.17 & 6.12 & 6.37 & 7.17 & 3.38 & 4.82 & 2.04 \\
\hline & Min. & 0 & 0 & 0 & 0 & 0 & 0 & 0 & 10 & 0 & 10 \\
\hline & Max. & 10 & 20 & 20 & 20 & 20 & 20 & 20 & 20 & 20 & 20 \\
\hline \multirow{4}{*}{ Bank size } & Mean & 15.90 & 16.12 & 16.45 & 16.53 & 16.76 & 16.89 & 17.08 & 17.25 & 17.30 & 17.44 \\
\hline & SD & 5.79 & 5.32 & 5.37 & 5.39 & 5.44 & 5.47 & 5.39 & 5.43 & 5.44 & 5.48 \\
\hline & Min. & 2.64 & 2.71 & 2.77 & 2.83 & 2.89 & 2.94 & 3.00 & \begin{tabular}{|l|}
3.04 \\
\end{tabular} & 3.09 & 3.14 \\
\hline & Max. & 20.17 & 20.27 & 20.45 & 20.52 & 20.67 & 20.76 & 20.87 & 21.20 & 21.26 & 21.29 \\
\hline \multirow{4}{*}{ Bank age } & Mean & 26.14 & 27.29 & 25.91 & 26.91 & 27.91 & 28.91 & 28.67 & 29.67 & 30.67 & 31.67 \\
\hline & SD & 30.61 & 30.49 & 30.12 & 30.12 & 30.12 & 30.12 & 30.08 & 30.08 & 30.08 & 30.08 \\
\hline & Min. & 2 & 1 & 1 & 2 & 3 & 4 & 5 & 1 & 2 & 3 \\
\hline & Max. & 121 & 122 & 123 & 124 & 125 & 126 & 127 & 128 & 129 & 130 \\
\hline \multirow{4}{*}{$\begin{array}{l}\text { Liquidity } \\
\text { ratio }\end{array}$} & Mean & 0.72 & 0.72 & 0.51 & 0.52 & 0.56 & 0.45 & 0.48 & 0.47 & 0.45 & 0.42 \\
\hline & SD & 2.56 & 2.76 & 1.92 & 2.00 & 2.25 & 1.73 & 1.90 & 1.90 & 1.80 & 1.66 \\
\hline & Min. & 0.09 & 0.08 & 0.04 & 0.03 & 0.05 & 0.05 & 0.04 & 0.03 & 0.05 & 0.05 \\
\hline & Max. & 11.30 & 13.40 & 9.30 & 9.70 & 10.90 & 8.40 & 9.40 & 9.40 & 8.90 & 8.24 \\
\hline \multirow{4}{*}{$\begin{array}{l}\text { Capital } \\
\text { adequacy } \\
\text { ratio }\end{array}$} & Mean & 0.13 & 0.19 & 0.19 & 0.16 & 0.15 & 0.14 & 0.18 & 0.16 & 0.15 & 0.15 \\
\hline & SD & 0.04 & 0.15 & 0.15 & 0.12 & 0.02 & 0.11 & 0.12 & 0.10 & 0.09 & 0.08 \\
\hline & Min. & 0.08 & 0.05 & 0.06 & 0.02 & 0.01 & -0.04 & 0.07 & -0.06 & -0.04 & -0.05 \\
\hline & Max. & 0.22 & 0.62 & 0.65 & 0.55 & 0.57 & 0.53 & 0.56 & 0.44 & 0.42 & 0.37 \\
\hline \multirow{4}{*}{$\begin{array}{l}\text { Growth in } \\
\text { assets }\end{array}$} & Mean & 0.13 & 0.47 & 0.68 & 0.52 & 0.35 & 0.16 & 0.14 & 0.09 & 0.09 & -0.03 \\
\hline & $\mathrm{SD}$ & 0.02 & 0.24 & 0.18 & 0.19 & \begin{tabular}{|l|}
0.19 \\
\end{tabular} & \begin{tabular}{|l|}
0.10 \\
\end{tabular} & 0.06 & 0.07 & 0.03 & 0.12 \\
\hline & Min. & 0.03 & 0.01 & -0.03 & -0.88 & -0.50 & -0.34 & -0.12 & -0.24 & -0.06 & -2.73 \\
\hline & Max. & 0.25 & 5.51 & 48.50 & 4.08 & 4.40 & \begin{tabular}{|l|}
2.13 \\
\end{tabular} & \begin{tabular}{|l}
1.18 \\
\end{tabular} & \begin{tabular}{|l|}
1.67 \\
\end{tabular} & 0.55 & 0.56 \\
\hline \multicolumn{2}{|c|}{$\begin{array}{l}\text { No of banks } \\
\text { (observations) }\end{array}$} & 19 & 23 & 23 & 23 & 23 & 23 & 24 & 24 & 24 & 24 \\
\hline
\end{tabular}

Source: authors' own calculations. 
THE CORPORATE GOVERNANCE AND EFFICIENCY OF COMMERCIAL BANKS IN PAKISTAN [...] 187

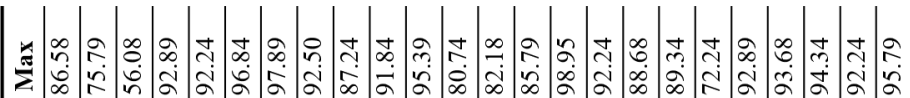

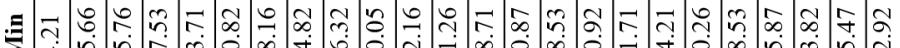

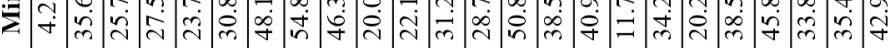

ค)

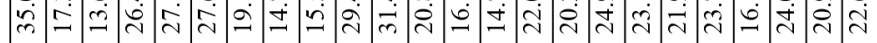

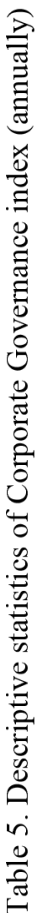

₹ ప के

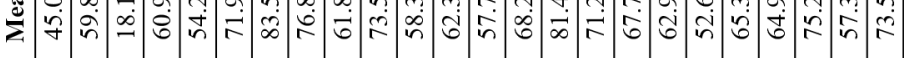

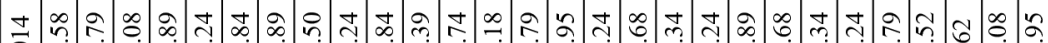

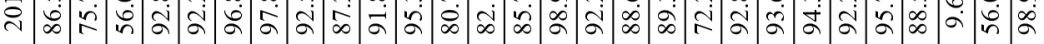

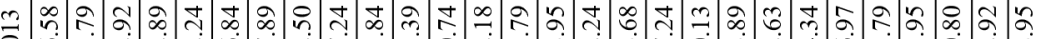
సे

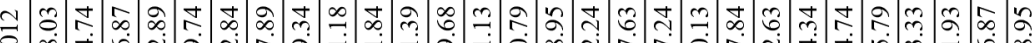

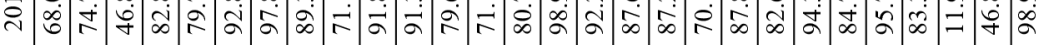

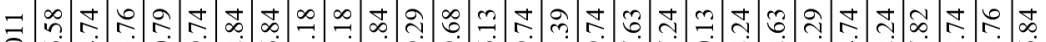

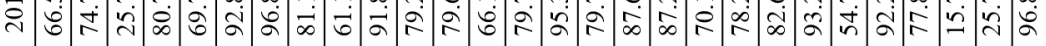

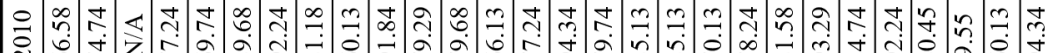

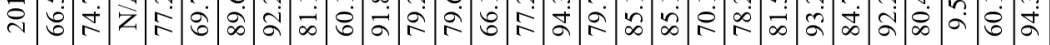

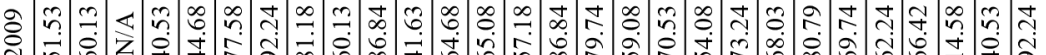
F

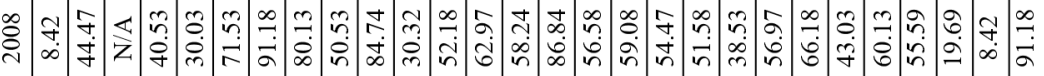

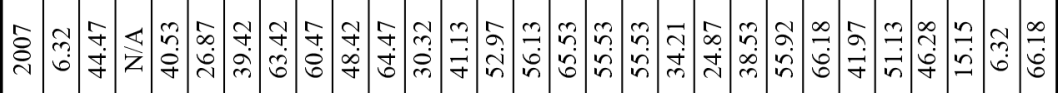
○)

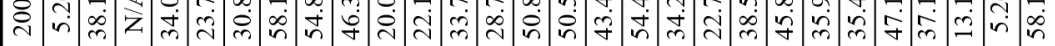

ڤڤ

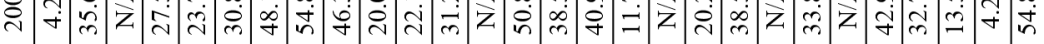

岸

올

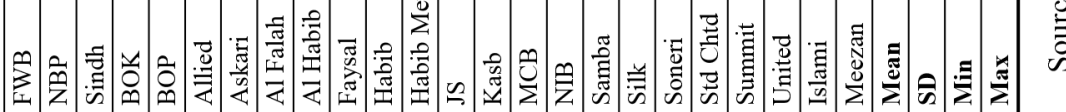


Table 6

Tobit regression results, 2005-2014

\begin{tabular}{|c|c|c|c|c|}
\hline \multirow{2}{*}{ Variables } & \multicolumn{2}{|c|}{ Cost efficiency } & \multicolumn{2}{|c|}{ Technical efficiency } \\
\hline & Coefficient & $p$-value & Coefficient & $p$-value \\
\hline 1 & 2 & 3 & 4 & 5 \\
\hline \multicolumn{5}{|c|}{ CG index (composite) } \\
\hline Constant & $0.5869^{* * *}$ & 0.0000 & $0.8818^{* * *}$ & 0.0000 \\
\hline CG index & $0.0020 * *$ & 0.0184 & $0.0008 * *$ & 0.0397 \\
\hline Bank size & $-0.0122 * * *$ & 0.0011 & 0.0000 & 0.9793 \\
\hline Bank age & 0.0000 & 0.9615 & $-0.0007^{* *}$ & 0.0206 \\
\hline Liquidity & -0.0140 & 0.1537 & $-0.0092 * *$ & 0.0339 \\
\hline Capital adequacy ratio & -0.2915 & 0.1204 & 0.0042 & 0.9637 \\
\hline Growth in total assets & -0.0021 & 0.5540 & 0.0016 & 0.3792 \\
\hline Mean dependent variable & \multicolumn{2}{|c|}{0.4494} & \multicolumn{2}{|c|}{0.8875} \\
\hline S.E. of regression & \multicolumn{2}{|c|}{0.2670} & \multicolumn{2}{|c|}{0.0963} \\
\hline Log likelihood & \multicolumn{2}{|c|}{-73.8455} & \multicolumn{2}{|c|}{34.9755} \\
\hline Avg. log likelihood & \multicolumn{2}{|c|}{-0.3253} & \multicolumn{2}{|c|}{0.1619} \\
\hline
\end{tabular}

Board of directors

\begin{tabular}{l|c|c|c|c}
\hline Constant & $0.5576^{* * *}$ & 0.0000 & $0.8977 * * *$ & 0.0000 \\
\hline Board of directors index & $0.0113^{* *}$ & 0.0106 & 0.0032 & 0.1186 \\
\hline Bank size & $-0.0132^{* * *}$ & 0.0003 & 0.0004 & 0.8107 \\
\hline Bank age & 0.0000 & 0.9464 & $-0.0008^{* * *}$ & 0.0067 \\
\hline Liquidity & -0.0122 & 0.1917 & $-0.0097 * *$ & 0.0216 \\
\hline Capital adequacy ratio & $-0.3085^{*}$ & 0.0850 & -0.0386 & 0.6732 \\
\hline Growth in total assets & -0.0025 & 0.4479 & 0.0011 & 0.5116 \\
\hline Mean dependent variable & \multicolumn{2}{|c|}{0.4395} & 0.8917 \\
\hline S.E. of regression & \multicolumn{2}{|c|}{0.2583} & 0.0934 \\
\hline Log-likelihood & -59.3396 & 35.9791 \\
\hline Avg. log likelihood & -0.2661 & \multicolumn{2}{l}{0.1705} \\
\hline
\end{tabular}

Audit committee

\begin{tabular}{l|c|c|c|c}
\hline Constant & $0.5677^{* * *}$ & 0.0000 & $0.9237^{* * *}$ & 0.0000 \\
\hline Audit committee index & $0.0070^{*}$ & 0.0568 & 0.0002 & 0.9261 \\
\hline Bank size & $-0.0140^{* * *}$ & 0.0000 & 0.0005 & 0.7713 \\
\hline Bank age & 0.0005 & 0.3757 & $-0.0006^{* *}$ & 0.0376 \\
\hline Liquidity & -0.0075 & 0.3818 & $-0.0081^{*}$ & 0.0633 \\
\hline Capital adequacy ratio & -0.2284 & 0.1637 & -0.0015 & 0.9875 \\
\hline Growth in total assets & -0.0014 & 0.6340 & 0.0014 & 0.4431 \\
\hline Mean dependent variable & \multicolumn{2}{|c|}{0.4219} & 0.8875 \\
\hline S.E. of regression & \multicolumn{2}{|c|}{0.2424} & 0.0972 \\
\hline Log likelihood & -34.5634 & 32.8734 \\
\hline Avg. log likelihood & -0.1600 & 0.1522 \\
\hline
\end{tabular}


THE CORPORATE GOVERNANCE AND EFFICIENCY OF COMMERCIAL BANKS IN PAKISTAN [...] 189

\begin{tabular}{l|c|c|c|c}
\hline & 2 & 3 & 4 & 5 \\
\hline \multicolumn{4}{c|}{ Disclosure and transparency } \\
\hline Constant & $0.4971^{* * *}$ & 0.0000 & $0.8513^{* * *}$ & 0.0000 \\
\hline Disclosure and transparency index & $0.0183^{* * *}$ & 0.0002 & $0.0069^{* * *}$ & 0.0020 \\
\hline Bank size & $-0.0119^{* * *}$ & 0.0011 & 0.0002 & 0.9226 \\
\hline Bank age & -0.0003 & 0.6528 & $-0.0008^{* * *}$ & 0.0068 \\
\hline Liquidity & -0.0109 & 0.2544 & -0. & 0.0592 \\
\hline Capital adequacy ratio & -0.2762 & 0.1334 & 0.0051 & 0.9555 \\
\hline Growth in total assets & -0.0021 & 0.5334 & 0.0016 & 0.3823 \\
\hline Mean dependent variable & \multicolumn{2}{|c|}{0.4494} & 0.8875 \\
\hline S.E. of regression & \multicolumn{2}{|c|}{0.2619} & 0.0951 \\
\hline Log likelihood & -69.7957 & 37.5845 \\
\hline Avg. log likelihood & \multicolumn{2}{|c|}{-0.3075} & 0.1740 \\
\hline
\end{tabular}

Remuneration committee

\begin{tabular}{|c|c|c|c|c|}
\hline Constant & $0.6370 * * *$ & 0.0000 & $0.9002 * * *$ & 0.0000 \\
\hline Remuneration committee index & $0.0062 * * *$ & 0.0098 & $0.0026^{* *}$ & 0.0193 \\
\hline Bank size & $-0.0105 * * *$ & 0.0047 & 0.0007 & 0.6573 \\
\hline Bank age & -0.0001 & 0.9216 & $-0.0007 * *$ & 0.0147 \\
\hline Liquidity & -0.0140 & 0.1500 & $-0.0092 * *$ & 0.0320 \\
\hline Capital adequacy ratio & -0.2520 & 0.1816 & 0.0209 & 0.8223 \\
\hline Growth in total assets & -0.0020 & 0.5719 & 0.0017 & 0.3569 \\
\hline Mean dependent variable & \multicolumn{2}{|c|}{0.4494} & \multicolumn{2}{|c|}{0.8875} \\
\hline S.E. of regression & \multicolumn{2}{|c|}{0.2666} & \multicolumn{2}{|c|}{0.0962} \\
\hline Log likelihood & \multicolumn{2}{|c|}{-73.2969} & \multicolumn{2}{|c|}{35.5968} \\
\hline Avg. log likelihood & \multicolumn{2}{|c|}{-0.3229} & \multicolumn{2}{|c|}{0.1648} \\
\hline \multicolumn{5}{|c|}{ Shareholders' rights } \\
\hline Constant & $0.6646 * * *$ & 0.0000 & $0.9247 * * *$ & 0.0000 \\
\hline Shareholders' rights index & $0.0060 * *$ & 0.0310 & $0.0024 *$ & 0.0578 \\
\hline Bank size & $-0.0144 * * *$ & 0.0001 & -0.0003 & 0.8777 \\
\hline Bank age & -0.0001 & 0.8761 & $-0.0009 * * *$ & 0.0039 \\
\hline Liquidity & -0.0123 & 0.1901 & $-0.0101 * *$ & 0.0160 \\
\hline Capital adequacy ratio & -0.2628 & 0.1432 & -0.0278 & 0.7594 \\
\hline Growth in total assets & -0.0020 & 0.5557 & 0.0013 & 0.4441 \\
\hline Mean dependent variable & \multicolumn{2}{|c|}{0.4395} & \multicolumn{2}{|c|}{0.8917} \\
\hline S.E. of regression & \multicolumn{2}{|c|}{0.2592} & \multicolumn{2}{|c|}{0.0926} \\
\hline Log likelihood & \multicolumn{2}{|c|}{-60.2607} & \multicolumn{2}{|c|}{36.5455} \\
\hline Avg. log likelihood & \multicolumn{2}{|c|}{-0.2702} & \multicolumn{2}{|c|}{0.1732} \\
\hline
\end{tabular}

* Significant at $10 \%, * *$ significant at $5 \%$, *** significant at $1 \%$

Source: authors' own calculations. 